\title{
APLIKASI EKSTRAK DAUN SALAM (SYZYGIUM POLYANTHUM) DAN EKSTRAK BIJI PINANG (Areca catech $u$ L.) SEBAGAI PENGAWET DAGING AYAM BROILER GILING SELAMA PROSES PENYIMPANAN
}

\author{
APPLICATION OF BAY LEAF EXTRACT (SYZYGIUM POLYANTHUM) \\ AND BETEL NUT EXTRACT (Areca catechu L.) AS A PRESERVATIVE OF \\ BROILER CHICKEN MINCED MEAT DURING STORAGE
}

\author{
Nur Her Riyadi $\mathbf{P}^{(1)}$, Windi Atmaka ${ }^{(1)}$ Arinta Happy $^{(1)}$ \\ ${ }^{1}$ Program Studi Ilmu dan Teknologi Pangan \\ Email : masnur_heri@yahoo.co.id
}

\begin{abstract}
The aims of this research were to evaluate the effect of bay leaf extracts and betel nut extracts on the microbiological and chemical characteristics of broiler chicken minced meat during storage and to evaluate the concentration of bay leaf extracts and betel nut extracts that provide inhibitory effect of broiler chicken minced meat spoilage based on microbiological and chemical characteristics of broiler chicken minced meat during storage. Analysis of this research were the content of tannins, Total Plate Count (TPC), pH, and Total Volatile Bases (TVB) that used a completely randomized design (CRD) with a treatment based on differences in the concentration of bay leaf extracts and betel nut extracts. In this study, the addition of 9 treatments with variations of bay leaf extract concentrations $(0 \%, 5 \%$ and $10 \%)$ and betel nut extract $(0 \%, 2.5 \%$, and $5 \%)$. Observed on day 0, day 1, day 2, day 4, and day 6. Statistical analysis was performed using SPSS 16.0 by analysis of varians (ANOVA). Duncan multiple range test was used to determine differences $(P<0,05)$. This experiment was conducted with 2 replications. The results showed that the bay leaf extracts and betel nut extracts contain tannins which can be inhibited decay in the broiler chicken minced meat are proved by the addition of bay leaf extracts and betel nut extracts on broiler chicken minced meat affect the value of total microbial, $p H$, and TVB. The addition of bay leaf extracts and betel nut extracts can be inhibited the growth of microorganism in the broiler chicken minced meat, so the shelf life increased up to 2 days. The higher concentration of bay leaf extract and betel nut extract, the value of TVB is lower. The concentration of bay leaf extract and betel nut extract that provided the inhibitory effect of broiler chicken minced meat spoilage for broiler chicken minced meat preservation based on microbiological and chemical characteristics of broiler chicken minced meat during storage is $10 \%$ of bay leaf extract and $2.5 \%$ of betel nut extract.
\end{abstract}

Keywords: bay leaf extract, betel nut extract, broiler chicken minced meat, storage, tannin, total microbial, total volatile bases

\section{ABSTRAK}

Penelitian ini bertujuan untuk mengetahui pengaruh penambahan ekstrak daun salam dan ekstrak biji pinang terhadap karakteristik mikrobiologis dan kimia daging ayam broiler giling selama proses penyimpanan serta mengetahui konsentrasi ekstrak daun salam dan ekstrak biji pinang yang memberikan efek penghambatan pembusukan daging ayam broiler giling, ditinjau berdasarkan karakteristik mikrobiologis dan kimia daging ayam broiler giling selama proses penyimpanan. Penelitian ini menggunakan empat macam analisis, diantaranya adalah kadar tanin, Total Plate Pount (TPC), pH, dan Total Volatile Bases (TVB). Rancangan percobaan pada penelitian ini menggunakan rancangan acak lengkap (RAL) dengan perlakuan berdasar perbedaan konsentrasi ekstrak daun salam dan ekstrak biji pinang yang digunakan. Pada penelitian ini digunakan 9 perlakuan dengan variasi penambahan konsentrasi ekstrak daun salam $(0 \% ; 5 \%$; dan $10 \%)$ dan ekstrak biji pinang $(0 \% ; 2,5 \%$; dan $5 \%$ ). Pengamatan dilakukan pada hari ke-0, hari ke-1, hari ke-2, hari ke-4 dan hari ke-6. Data yang diperoleh dianalisis dengan ANOVA dengan alfa 0,05. Percobaan ini dilakukan dengan 2 kali ulangan. Hasil analisis menunjukkan bahwa ekstrak daun salam dan ekstrak pinang mengandung tanin yang dapat menghambat pembusukan pada daging ayam broiler giling, terbukti dengan penambahan ekstrak daun salam dan ekstrak biji pinang pada daging ayam broiler giling berpengaruh terhadap nilai Total Mikroba, $\mathrm{pH}$, dan TVB. Penambahan ekstrak daun salam dan ekstrak biji pinang dapat menghambat pertumbuhan mikroba yang terdapat dalam daging ayam broiler giling, sehingga masa penyimpanan meningkat menjadi 2 hari. Semakin tinggi konsentrasi ekstrak daun salam dan ekstrak biji pinang maka nilai TVB yang dihasilkan semakin rendah. Konsentrasi ekstrak daun salam dan ekstrak biji pinang yang memberikan efek penghambatan pembusukan daging ayam broiler giling yang baik untuk pengawetan daging ayam broiler giling berdasarkan karakteristik mikrobiologis dan kimia daging ayam broiler giling selama proses penyimpanan adalah $10 \%$ ekstrak daun salam dan $2,5 \%$ ekstrak biji pinang.

Kata kunci: daging ayam broiler giling, ekstrak biji pinang, ekstrak daun salam, penyimpanan, tanin, total mikroba, total volatile bases 


\section{PENDAHULUAN}

Daging ayam mudah mengalami kerusakan karena kaya akan nutrisi, memiliki Aw yang relatif tinggi, dan memiliki nilai $\mathrm{pH}$ mendekati netral yang merupakan media yang baik untuk pertumbuhan dan perkembangbiakan mikroba sehingga menyebabkan daging memiliki umur simpan yang relatif rendah. Oleh sebab itu, perlu adanya perlakuan yang dapat memperpanjang umur simpan daging menjadi lebih lama.

Beberapa perlakuan yang dilakukan untuk memperpanjang umur simpan daging yang paling umum yaitu pendinginan. Perlakuan lainnya yaitu dengan penambahan bahan pengawet pada daging. Bahan tambahan pengawet tersebut dapat ditambahkan untuk membantu mempertahankan kualitas produk. Pada prinsipnya bahan tambahan tersebut mampu memberikan keawetan melalui mekanisme yaitu penurunan aktivitas air (Aw), penurunan $\mathrm{pH}$, aktivitas anti mikroba, aktivitas antioksidan, atau kombinasinya (Muwarni, 2012).

Daun salam dan biji pinang memiliki senyawa antimikroba yang dapat berperan dalam pengawetan daging. Ekstrak daun salam memiliki aktivitas antimikrobia terhadap Bacillus sp., Pseudomonas sp., Salmonella enteric, dan E. coli pada konsentrasi 10\% (Olaitan et al., 2010). Ekstrak biji pinang dapat menghambat pertumbuhan $S$. aureus pada konsentrasi $1,57 \%$ dan Pseudomonas aeruginosa pada konsentrasi 25\% (Puspawati, 2008).

\section{METODE PENELITIAN}

\section{Bahan dan Alat}

Bahan utama yang digunakan pada penelitian ini adalah daging ayam broiler, daun salam, dan biji pinang. Untuk ekstraksi menggunakan pelarut etanol 96\% dan etanol $70 \%$. Bahan kimia untuk analisis tanin menggunakan asam tanat, Folin Ciocalteu $1 \mathrm{~N}$, dan $\mathrm{Na}_{2} \mathrm{CO}_{3} \cdot 10 \mathrm{H}_{2} \mathrm{O}$ $20 \%$. Untuk analisis total mikroba adalah plate count agar (PCA) dan larutan garam fisiologis. Untuk analisis total volatile bases adalah TCA 5\%, $\mathrm{NaOH}, \mathrm{HCl}$, dan indikator phenol red. Untuk uji $\mathrm{pH}$ menggunakan aquades.

Alat untuk persiapan daging yaitu penggiling daging Tecstar TC-56, lemari pendingin dan cup polipropilen. Alat untuk persiapan ekstrak yaitu cabinet dryer, ayakan 30 mesh, rotary evaporator, botol vial, dan aluminium foil. Alat untuk analisis tanin menggunakan spektrofotometer dan pendingin balik. Seperangkat alat untuk analisis total mikroba. Alat untuk analisis total volatile bases menggunakan labu Kjeldahl dan seperangkat alat titrasi. Analisis $\mathrm{pH}$ menggunakan $\mathrm{pH}$ meter.

\section{Tahapan Penelitian}

\section{Pembuatan ekstrak daun salam}

Daun salam dikeringkan pada suhu ruang selama 1-2 hari. Setelah kering, daun salam diblender hingga diperoleh bubuk daun salam. Bubuk daun salam tersebut direndam dengan etanol $96 \%$ selama 24 jam. Kemudian disaring dan dievaporasi dengan rotary evaporator hingga diperoleh ekstrak pekat (Vardapetyan et al., 2013).

\section{Pembuatan ekstrak biji pinang}

Biji pinang ditumbuk, kemudian dikeringkan dengan cabinet dryer pada suhu $70^{\circ} \mathrm{C}$ selama 2 jam, setelah kering dibuat serbuk dan diayak dengan ayakan 30 mesh. Bubuk biji pinang dimaserasi menggunakan etanol $70 \%$ selama 6 hari. Ekstrak yang diperoleh kemudian dipekatkan dengan rotary evaporator (Puspawati, 2008).

\section{Pencampuran ekstrak pada daging ayam giling}

Ekstrak daun salam $(0 \%, 5 \%$, dan $10 \%)$ dan ekstrak biji pinang $(0 \%, 2,5 \%$, dan $5 \%$ ) ditambahkan aquades $10 \%$ yang sebelumnya telah disterilisasi pada suhu $121^{\circ} \mathrm{C}$ selama 15 menit. Kemudian dihomogenisasi selama 1 menit dengan kecepatan putar $1000 \mathrm{rpm}$. Setelah ekstrak homogen, kemudian dicampurkan ke dalam daging ayam broiler giling hingga tercampur merata. Setelah itu, daging ayam 
broiler giling yang telah diberi ekstrak dikemas dalam cup polipropilen dan disimpan pada suhu $2^{\circ} \mathrm{C}$.

\section{Analisis}

Analisis yang dilakukan terdiri dari analisis tanin dengan metode Folin Ciocalteu (Makkar, 1993), total mikroba dengan metode total plate count (Fardiaz, 1987), total volatile bases dengan metode Kjeldahl (Apriyantono et al., 1988), dan uji $\mathrm{pH}$ dengan $\mathrm{pH}$ meter (FSSAI, 2012). Analisis statistik dengan SPSS menggunakan ANOVA. Jika terdapat perbedaan antar sampel maka dilanjutkan dengan uji beda nyata menggunakan analisis Duncan Multiple Range Test (DMRT) pada tingkat signifikansi $\alpha=$ 0,05 .

\section{HASIL DAN PEMBAHASAN}

\section{Kadar Tanin Dalam Ekstrak Daun Salam dan Ekstrak Biji Pinang}

Tabel 1. Kadar Tanin Ekstrak Daun Salam dan Ekstrak Biji Pinang

\begin{tabular}{ll}
\hline Ekstrak & Kadar (\%) \\
\hline Bubuk daun salam & $2,13^{\mathrm{a}}$ \\
Ekstrak daun salam & $12,17^{\mathrm{c}}$ \\
Bubuk biji pinang & $9,30^{\mathrm{b}}$ \\
Ekstrak biji pinang & $19,12^{\mathrm{d}}$ \\
\hline Keterangan : Angka yang diikuti huruf yang berbeda pada kolom \\
$\quad$ yang sama menunjukan adanya beda nyata pada $\alpha$ \\
$\quad=0,05$ \\
Dari Tabel & 1, kadar tanin ekstrak
\end{tabular}
daun salam dan biji pinang dalam bentuk bubuk lebih kecil dibandingkan dalam bentuk ekstrak. Hal ini disebabkan oleh adanya pelarut etanol $96 \%$ pada ekstrak daun salam dan pelarut etanol $70 \%$ pada ekstrak biji pinang. Adanya pelarut tersebut mampu mengekstrak komponen tanin sehingga diperoleh kadar tanin ekstrak lebih besar dibandingkan bubuk (Gani et al., 2013). Pada umumnya pelarut yang digunakan untuk mengekstraksi senyawa tanin yaitu pelarut etanol. Hal ini disebabkan pelarut etanol lebih efektif mengekstrak senyawa tanin karena polaritas etanol lebih mendekati polaritas senyawa tanin (Gani et al., 2013). Bubuk daun salam secara analisis statistik berbeda nyata dengan ekstrak daun salam. Begitu pula, kadar tanin bubuk biji pinang berbeda nyata dengan kadar tanin ekstrak biji pinang pada tingkat signifikansi 0,05. Bubuk dan ekstrak biji pinang memiliki kadar tanin sebesar 9,30\% dan 19,12\%. Jumlah tersebut lebih besar dibandingkan dengan bubuk dan ekstrak daun salam yang hanya sebesar 2,13\% dan 12,17\%.

Pada Gambar 1 perbedaan kadar tanin bubuk dan ekstrak daun salam dan biji pinang yang berbeda nyata ini disebabkan oleh adanya proses ekstraksi dengan pelarut etanol $96 \%$ pada ekstrak daun salam dan pelarut etanol $70 \%$ pada ekstrak biji pinang. Adanya pelarut etanol tersebut menyebabkan senyawa tanin menjadi larut karena etanol memiliki gugus hidroksil. Gugus hidroksil yaitu gugus yang sangat polar karena elektronegatif dari oksigen tinggi yang memungkinkan ikatan hidrogen bertukar tempat dengan molekul lain sehingga diperoleh kadar tanin yang lebih besar pada ekstrak daun salam dan ekstrak biji pinang dibandingkan dengan bubuknya (Gani et al., 2013). Penggunaan pelarut pada proses ekstraksi berperan untuk meningkatkan kadar senyawa tanin pada ekstrak daun salam dan biji pinang yang mengalami kontak langsung selama waktu tertentu (Mawaddah, 2008). Belum digunakannya pelarut etanol pada bubuk daun salam dan biji pinang menyebabkan senyawa tanin kurang terekstrak sempurna sehingga kadar tanin yang dihasilkan kecil. Bubuk biji pinang diperoleh kadar tanin sebesar $9,30 \%$. Hal ini sesuai dengan penelitian Jaiswal et al. (2011), bahwa kandungan tanin pada biji pinang sebesar $8-18 \%$.

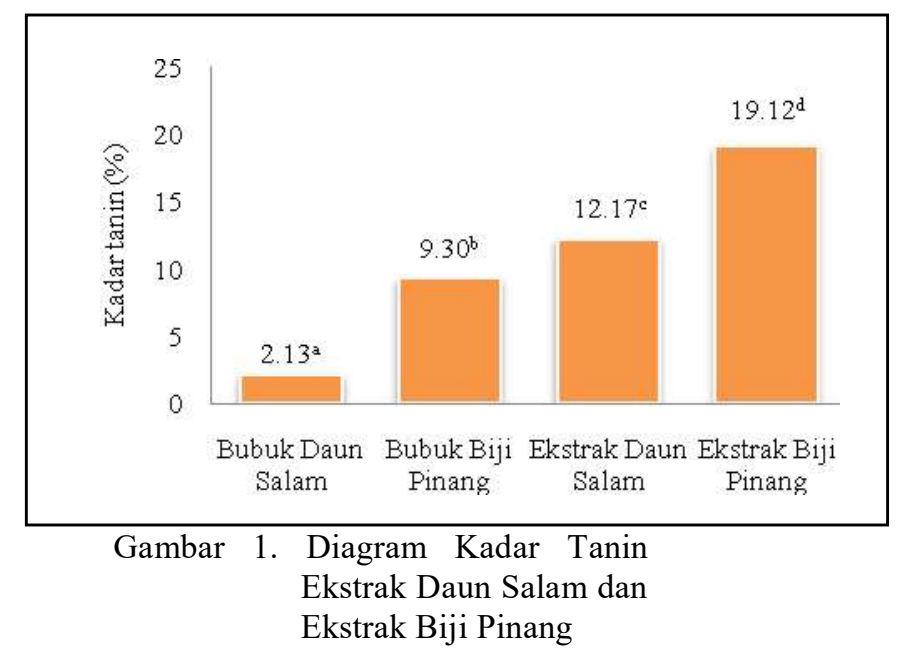


Dari hasil uji diperoleh kadar tanin ekstrak biji pinang dan ekstrak daun salam sebesar 19,12\% dan 12,17\%. Hasil uji tersebut berbeda dengan beberapa penelitian yang telah dilakukan. Menurut penelitian Wetwitayaklung et al. (2006) dan Hannan et al. (2012) biji pinang yang diekstrak dengan metanol mengandung tanin sebesar $47-54 \%$ dan 54\%. Sedangkan kandungan tanin pada ekstrak daun salam yang diekstrak dengan menggunakan pelarut metanol yaitu sebesar 4,53 mg/g (Deepa et al., 2013). Perbedaan hasil uji ini diduga karena pelarut yang digunakan berbeda. Pada ekstrak daun salam menggunakan pelarut etanol 96\% sedangkan ekstrak biji pinang menggunakan pelarut etanol $70 \%$. Pelarut etanol $70 \%$ lebih polar dibandingkan pelarut etanol $96 \%$ karena semakin tinggi konsentrasi etanol maka sifatnya semakin non-polar sehingga tanin yang terekstrak semakin sedikit karena tanin bersifat polar (Gani et al., 2013).

\section{Karakteristik Mikrobiologi dan Kimia Daging Ayam Broiler Giling}

\section{Total Plate Count (TPC)}

Dari Tabel 2, dapat dilihat bahwa secara keseluruhan jumlah mikroba pada masing-masing sampel meningkat seiring dengan lamanya waktu penyimpanan. Pada pengamatan hari ke-0 menunjukkan jumlah mikroba awal pada daging ayam giling sebesar 5,07 log cfu/g sampel pada semua perlakuan. Pada pengamatan hari ke-1 menunjukkan peningkatan dan penurunan jumlah mikroba pada sampel yang diberi penambahan ekstrak.

Pada sampel kontrol hari ke-1 menunjukkan jumlah mikroba tetap sebesar 5,07 log cfu/g sampel. Pada sampel dengan penambahan ekstrak daun salam $10 \%$ menunjukkan jumlah mikroba menurun secara signifikan sebesar 4,54 log $\mathrm{cfu} / \mathrm{g}$ sampel. Hal ini disebabkan ekstrak daun salam 10\% mengandung senyawa antimikroba dan antioksidan seperti flavonoid, polifenol, dan senyawa minyak atsiri (Vardapetyan et al., 2013). Pada sampel dengan penambahan pinang 2,5\%, pinang $5 \%$, salam $5 \%$ dan pinang $2,5 \%$, serta salam $10 \%$ dan pinang $2,5 \%$ menunjukkan jumlah mikroba yang tidak begitu berbeda, masing-masing sebesar 4,$85 ; 4,83 ; 4,83 ;$ dan 4,82 log cfu/g sampel. Perlakuan dengan penambahan ekstrak biji pinang menunjukkan penurunan jumlah mikroba karena ekstrak ini mengandung tanin yang lebih tinggi dibandingkan dengan ekstrak salam. Sedangkan pada penambahan ekstrak daun salam 5\%, ekstrak daun salam 5\% dan biji pinang $5 \%$, serta ekstrak daun salam 10\% dan biji pinang 5\% menunjukkan peningkatan jumlah mikroba masingmasing sebesar 5,09; 5,10; dan 5,40 log cfu/g sampel. Hal ini diduga karena adanya asam lemak tidak jenuh yang tinggi pada ekstrak biji pinang sebesar 48,20\% dari total kandungan minyak (Zhang et al., 2011). Hal ini mempengaruhi terjadinya oksidasi lemak pada daging ayam broiler giling sehingga ekstrak yang ditambahkan dapat berperan sebagai prooksidan yang menghasilkan efek antagonisme terhadap daging ayam broiler giling (Dave dan Ghaly, 2011).

Pada pengamatan hari ke-2 menunjukkan sampel kontrol (tanpa penambahan ekstrak) mengalami peningkatan jumlah mikroba sebesar 5,58 $\log \mathrm{cfu} / \mathrm{g}$ sampel. Jumlah mikroba pada sampel dengan penambahan ekstrak daun salam $10 \%$ juga meningkat menjadi 5,11 $\log \mathrm{cfu} / \mathrm{g}$ sampel. Jumlah mikroba pada pengamatan hari ke-2 tidak berbeda nyata pada sampel dengan penambahan ekstrak daun salam 5\% (5,27 log cfu/g sampel), ekstrak biji pinang 2,5\% (5,24 log cfu/g sampel), ekstrak biji pinang 5\% (5,24 log cfu/g sampel), ekstrak daun salam 5\% dan biji pinang 2,5\% (5,17 log cfu/g sampel), ekstrak daun salam 5\% dan biji pinang 5\% (5,29 log cfu/g sampel), ekstrak daun salam $10 \%$ dan biji pinang 2,5\% (5,38 log cfu/g sampel), dan ekstrak daun salam 10\% dan biji pinang 5\% $(5,16 \log \mathrm{cfu} / \mathrm{g}$ sampel $)$. Pada pengamatan hari ke-4 menunjukkan sampel kontrol dan sampel dengan perlakuan ekstrak daun salam telah mengalami kerusakan karena telah melebihi batas jumlah mikroba pada 
Tabel 2. TPC Daging Ayam Giling Dengan Penambahan Ekstrak Daun Salam dan Ekstrak Biji Pinang

\begin{tabular}{|c|c|c|c|c|c|}
\hline \multirow{2}{*}{ Konsentrasi Ekstrak } & \multicolumn{5}{|c|}{ Lama Penyimpanan (Hari) } \\
\hline & 0 & 1 & 2 & 4 & 6 \\
\hline A1 & $5,07_{a}^{\mathrm{A}}$ & $5,07^{\mathrm{BC}}$ & $5,58^{\mathrm{B}}{ }_{\mathrm{b}}$ & $7,34^{\mathrm{C}}$ & $7,67_{c}^{\mathrm{C}}$ \\
\hline B1 & $5,07_{\mathrm{a}}^{\mathrm{A}}$ & $5,09^{\mathrm{B}}$ & $5,27^{\mathrm{AB}}$ & $7,02^{\mathrm{BC}}{ }_{\mathrm{b}}$ & $7,17^{\mathrm{AB}}$ \\
\hline $\mathrm{C} 1$ & $5,07_{\mathrm{b}}^{\mathrm{A}}$ & $4,54_{a}^{\mathrm{A}}$ & $5,11^{\mathrm{A}} \mathrm{b}$ & $7,01_{\mathrm{c}}^{\mathrm{BC}}$ & $7,12^{\mathrm{AB}}$ \\
\hline $\mathrm{A} 2$ & $5,07_{\mathrm{a}}^{\mathrm{A}}$ & $4,85^{\mathrm{AB}}$ & $5,24^{\mathrm{AB}}{ }_{\mathrm{b}}$ & $6,45_{c}^{\mathrm{AB}}$ & $7,17^{\mathrm{AB}}{ }_{\mathrm{d}}$ \\
\hline A3 & $5,07_{\mathrm{a}}^{\mathrm{A}}$ & $4,83^{\mathrm{AB}}$ & $5,24^{\mathrm{AB}}$ & $6,23^{\mathrm{A}}{ }_{\mathrm{b}}$ & $7,29^{\mathrm{B}}$ \\
\hline B2 & $5,07_{\mathrm{a}}^{\mathrm{A}}$ & $4,83^{\mathrm{AB}}$ & $5,17^{\mathrm{AB}}$ & $6,70_{b}^{A B}$ & $7,05^{\mathrm{AB}}$ \\
\hline B3 & $5,07_{\mathrm{a}}^{\mathrm{A}}$ & $5,10_{\mathrm{a}}^{\mathrm{BC}}$ & $5,29^{\mathrm{AB}}$ a & $6,51_{b}^{A B}$ & $7,14_{\mathrm{c}}^{\mathrm{AB}}$ \\
\hline $\mathrm{C} 2$ & $5,07^{\mathrm{A}}{ }_{\mathrm{b}}$ & $4,82^{\mathrm{AB}}{ }_{\mathrm{a}}$ & $5,38^{\mathrm{AB}}$ & $6,33_{d}^{A}$ & $6,89^{\mathrm{A}}$ \\
\hline C3 & $5,07_{\mathrm{a}}^{\mathrm{A}}$ & $5,40^{\mathrm{C}}{ }_{\mathrm{a}}$ & $5,16^{\mathrm{AB}}$ & $6,83^{\mathrm{ABC}}$ & $7,12^{\mathrm{AB}} \mathrm{b}$ \\
\hline
\end{tabular}

Keterangan : dalam log cfu/g sampel

Huruf kecil yang sama pada kolom yang sama tiap parameter uji dan huruf besar yang sama pada baris yang sama menunjukkan tidak beda nyata pada taraf signifikansi $(\alpha=0,05)$

A1 : Penambahan ekstrak daun salam $0 \%$ dan ekstrak biji pinang $0 \%$ (kontrol)

A2 : Penambahan ekstrak daun salam $0 \%$ dan ekstrak biji pinang 2,5\%

A3 : Penambahan ekstrak daun salam $0 \%$ dan ekstrak biji pinang $5 \%$

B1 : Penambahan ekstrak daun salam $5 \%$ dan ekstrak biji pinang $0 \%$

B2 : Penambahan ekstrak daun salam $5 \%$ dan ekstrak biji pinang 2,5\%

B3 : Penambahan ekstrak daun salam $5 \%$ dan ekstrak biji pinang $5 \%$

C1 : Penambahan ekstrak daun salam $10 \%$ dan ekstrak biji pinang $0 \%$

C2 : Penambahan ekstrak daun salam $10 \%$ dan ekstrak biji pinang 2,5\%

C3 : Penambahan ekstrak daun salam $10 \%$ dan ekstrak biji pinang $5 \%$

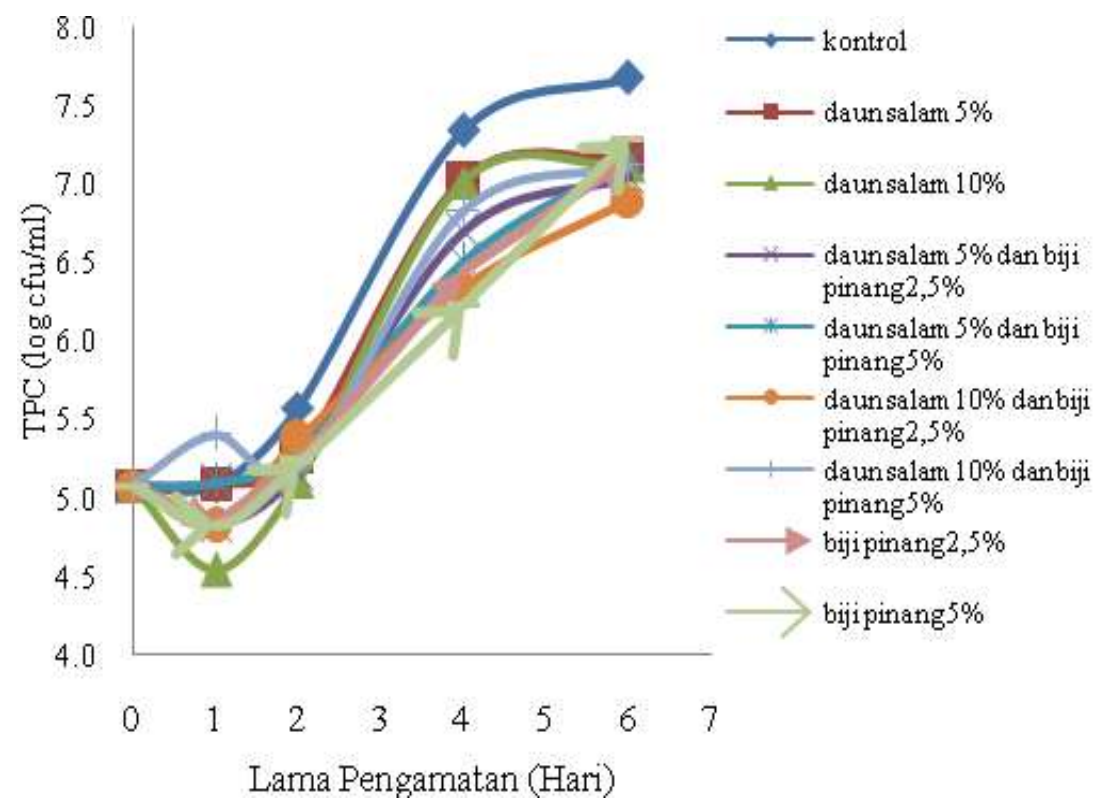

Gambar 2. Total Plate Count (TPC)

daging yaitu $7 \log \mathrm{cfu} / \mathrm{g}$ sampel (Lin et al., 2004). Sampel kontrol (tanpa penambahan ekstrak) mengalami peningkatan jumlah mikroba yang signifikan sebesar 7,34 log $\mathrm{cfu} / \mathrm{g}$ sampel. Pada sampel dengan penambahan ekstrak biji pinang 5\% dan ekstrak daun salam $10 \%$ dan pinang 2,5\% menunjukkan jumlah mikroba lebih kecil diantara sampel lainnya pada hari ke-4 yaitu sebesar 6,23 dan 6,33 log $\mathrm{cfu} / \mathrm{g}$ sampel.

Pada hari ke-6 semua sampel juga telah mengalami kerusakan dengan jumlah mikroba mencapai 7,67 log cfu/g sampel untuk sampel kontrol. Sampel dengan penambahan ekstrak campuran daun salam 
$10 \%$ dan biji pinang 5\% mencapai 6,89 log cfu/g sampel dan merupakan sampel dengan jumlah terendah pada hari ke-6. Pada sampel dengan penambahan konsentrasi ekstrak daun salam dan biji pinang lainnya berkisar antara 7,05 - 7,29 $\log \mathrm{cfu} / \mathrm{g}$ sampel. Menurut Lin et al. (2004), indikasi awal kerusakan daging ayam segar adalah timbulnya off-odor ketika jumlah mikroba mencapai 7 log cfu/g sampel.

Pada Gambar 2 dapat dilihat grafik TPC, semua sampel mengalami peningkatan jumlah mikroba dengan seiring lamanya waktu penyimpanan. Akan tetapi, pada hari ke-1 hampir seluruh sampel mengalami penurunan jumlah mikroba. Hal ini disebabkan ekstrak salam dan pinang memiliki aktivitas antibakteri. Senyawa antibakteri akan merusak sintesa peptidoglikan dengan cara menyerang gugus polar (gugus fosfat) sehingga molekul fosfolipid akan terurai menjadi gliserol, asam karboksilat, dan asam fosfat. Hal ini mengakibatkan fosfolipid tidak mampu mempertahankan bentuk membran sel sehingga pembentukan dinding sel menjadi kurang sempurna. Keadaan ini akan menyebabkan sel bakteri menjadi lisis karena tekanan osmotik maupun fisik sehingga sel bakteri menjadi mati (Puspita dan Muktiana, 2011). Dalam penelitian Olaitan et al. (2010) menunjukkan bahwa jumlah bakteri pada daging sapi sebelum diberi perlakuan ekstrak daun salam yaitu 7,28 log cfu/g sampel, setelah diberi perlakuan ekstrak daun salam menunjukkan penurunan jumlah bakteri menjadi 3,20 log cfu/g sampel.

Sedangkan sampel dengan penambahan ekstrak daun salam $10 \%$ dan biji pinang 5\% pada hari ke-1 mengalami peningkatan jumlah mikroba. Hal ini diduga karena adanya asam lemak tidak jenuh yang tinggi pada ekstrak biji pinang sebesar 48,20\% dari total kandungan minyak (Zhang et al., 2011). Hal ini mempengaruhi terjadinya oksidasi lemak pada daging ayam broiler giling sehingga ekstrak yang ditambahkan dapat berperan sebagai prooksidan yang menghasilkan efek antagonisme terhadap daging ayam broiler giling (Dave dan Ghaly, 2011). Pada hari ke-6, sampel dengan penambahan ekstrak daun salam $10 \%$ dan biji pinang 2,5\% memiliki penghambatan jumlah mikroba paling besar dibandingkan sampel lainnya. Mikroba yang dominan tumbuh pada sampel daging ayam giling ini diduga Pseudomonas sp. (Lin et al., 2004). Mikroba ini merupakan bakteri predominan pada daging yang disimpan secara aerob. Akan tetapi, sampel daging ayam giling dalam penelitian ini disimpan dalam kemasan cup polipropilen yang dibungkus dengan plastik wrap menyebabkan kondisi daging menjadi anaerob sehingga memungkinkan Enterobacter tumbuh. Enterobacter merupakan bakteri penyebab utama kerusakan pada daging segar yang dapat tumbuh pada kondisi aerob maupun anaerob dengan pH tinggi (Doyle, 2007).

\section{Derajat Keasaman (pH)}

Nilai $\mathrm{pH}$ memiliki peran penting dalam pertumbuhan mikroba yang berpengaruh terhadap kualitas daging. Tabel 3 menunjukkan hasil uji sampel daging ayam giling dengan penambahan ekstrak daun salam dan ekstrak biji pinang dengan berbagai konsentrasi.

Dari Tabel 3, terlihat bahwa $\mathrm{pH}$ awal daging ayam giling yaitu sebesar 5,76. Pada hari ke-1 menunjukkan $\mathrm{pH}$ sampel daging ayam giling yang fluktuatif. Pada sampel dengan penambahan ekstrak pinang 5\% mengalami kenaikan $\mathrm{pH}$ yang signifikan menjadi 5,80, berbeda dengan sampel lainnya yang sebagian besar memiliki $\mathrm{pH}$ tetap maupun turun menjadi 5,70 untuk sampel dengan penambahan ekstrak daun salam 5\%. Pada hari ke-2, terjadi peningkatan $\mathrm{pH}$ yang signifikan pada sampel yang diberi perlakuan dengan penambahan ekstrak daun salam dan ekstrak biji pinang. Sedangkan pada sampel kontrol mengalami penurunan $\mathrm{pH}$ dari 5,76 menjadi 5,73. Pada hari ke-4, menunjukkan beberapa sampel masih mengalami peningkatan $\mathrm{pH}$ seperti sampel dengan penambahan ekstrak daun salam $5 \%$, ekstrak biji pinang 5\%, serta campuran ekstrak daun salam 10\% dan biji 
Tabel 3. Nilai pH Daging Ayam Giling Dengan Penambahan Ekstrak Daun Salam dan Ekstrak Biji Pinang

\begin{tabular}{|c|c|c|c|c|c|}
\hline \multirow{2}{*}{ Konsentrasi Ekstrak } & \multicolumn{5}{|c|}{ Lama Penyimpanan (Hari) } \\
\hline & 0 & 1 & 2 & 4 & 6 \\
\hline A1 & $5,76_{\mathrm{c}}^{\mathrm{A}}$ & $5,76^{\mathrm{BC}}$ & $5,73_{b}^{A}$ & $5,77_{\mathrm{c}}^{\mathrm{ABC}}$ & $5,64_{a}^{\mathrm{A}}$ \\
\hline $\mathrm{B} 1$ & $5,76^{\mathrm{A}}{ }_{\mathrm{b}}$ & $5,70^{\mathrm{A}}$ & $5,72^{\mathrm{A}}{ }_{\mathrm{ab}}$ & $5,76^{\mathrm{AB}}$ & $5,72^{\mathrm{BC}} \mathrm{ab}$ \\
\hline $\mathrm{C} 1$ & $5,76^{\mathrm{A}}{ }_{\mathrm{b}}$ & $5,74^{\mathrm{B}}{ }_{\mathrm{b}}^{\mathrm{a}}$ & $5,81_{\mathrm{c}}^{\mathrm{CD}}$ & $5,75^{\mathrm{A}}$ & $5,69^{\mathrm{B}}{ }_{\mathrm{a}}$ \\
\hline $\mathrm{A} 2$ & $5,76^{\mathrm{A}} \mathrm{ab}$ & $5,78^{\mathrm{BC}} \mathrm{b}$ & $5,75^{\mathrm{AB}}$ & $5,88^{\mathrm{E}}{ }_{\mathrm{d}}$ & $5,84^{\mathrm{E}}{ }_{\mathrm{c}}$ \\
\hline A3 & $5,76_{a}^{\mathrm{A}}$ & $5,80^{\mathrm{C}}{ }_{\mathrm{b}}$ & $5,81_{\mathrm{b}}^{\mathrm{D}}$ & $5,80_{b}^{\mathrm{D}}$ & $5,80_{\mathrm{b}}^{\mathrm{DE}}$ \\
\hline $\mathrm{B} 2$ & $5,76^{\mathrm{A}}{ }_{\mathrm{ab}}$ & $5,76^{\mathrm{BC}}$ & $5,78^{\mathrm{CD}}$ & $5,76^{\mathrm{AB}}$ & $5,78^{\mathrm{D}}$ \\
\hline B3 & $5,76^{\mathrm{A}}{ }_{\mathrm{ab}}$ & $5,75^{\mathrm{B}}$ & $5,79^{\mathrm{CD}}$ & $5,77^{\mathrm{ABC}}{ }_{\mathrm{bc}}$ & $5,78_{\mathrm{c}}^{\mathrm{D}}$ \\
\hline $\mathrm{C} 2$ & $5,76^{\mathrm{A}}{ }_{\mathrm{ab}}$ & $5,76^{\mathrm{BC}}$ & $5,78^{\mathrm{BC}}{ }_{\mathrm{ab}}$ & $5,79^{\mathrm{CD}}$ & $5,77^{\mathrm{CD}}{ }_{\mathrm{ab}}$ \\
\hline $\mathrm{C} 3$ & $5,76^{\mathrm{A}}{ }_{\mathrm{ab}}$ & $5,76^{\mathrm{BC}}$ & $5,78^{\mathrm{BC}}$ & $5,78^{\mathrm{BC}}$ & $5,73^{\mathrm{BC}}$ \\
\hline
\end{tabular}

Keterangan :

Huruf kecil yang sama pada kolom yang sama tiap parameter uji dan huruf besar yang sama pada baris yang sama menunjukkan tidak beda nyata pada taraf signifikansi $(\alpha=0,05)$

A1 : Penambahan ekstrak daun salam $0 \%$ dan ekstrak biji pinang $0 \%$ (kontrol)

A2 : Penambahan ekstrak daun salam $0 \%$ dan ekstrak biji pinang $2,5 \%$

A3 : Penambahan ekstrak daun salam $0 \%$ dan ekstrak biji pinang $5 \%$

B1 : Penambahan ekstrak daun salam $5 \%$ dan ekstrak biji pinang $0 \%$

B2 : Penambahan ekstrak daun salam $5 \%$ dan ekstrak biji pinang 2,5\%

B3 : Penambahan ekstrak daun salam $5 \%$ dan ekstrak biji pinang $5 \%$

$\mathrm{C} 1$ : Penambahan ekstrak daun salam $10 \%$ dan ekstrak biji pinang $0 \%$

$\mathrm{C} 2$ : Penambahan ekstrak daun salam $10 \%$ dan ekstrak biji pinang 2,5 \%

C3 : Penambahan ekstrak daun salam $10 \%$ dan ekstrak biji pinang $5 \%$

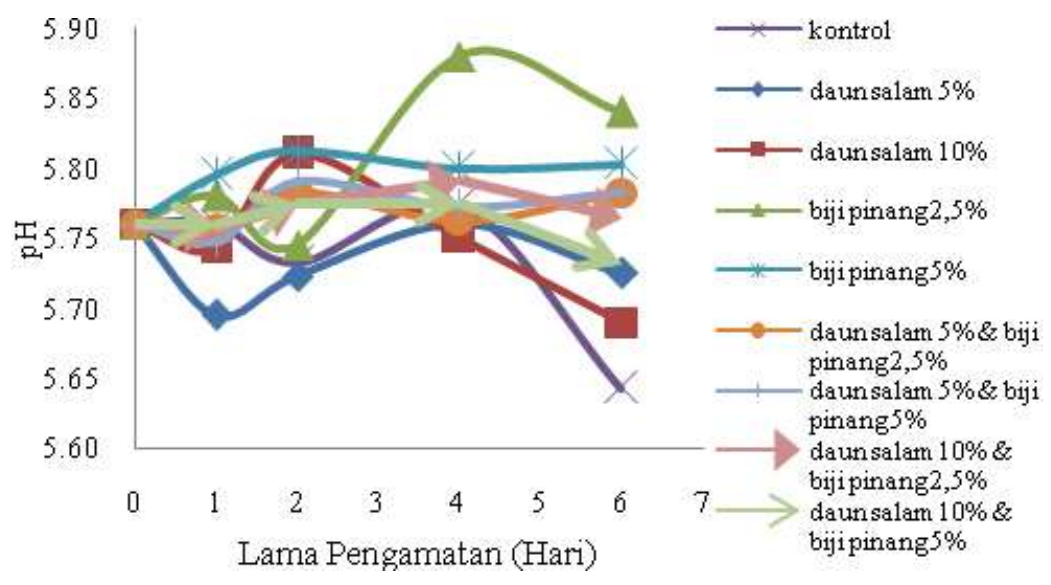

Gambar 3. Derajat Keasaman $(\mathrm{pH})$

pinang 2,5\%, masing-masing menjadi 5,76; 5,88; dan 5,79. Sedangkan sampel lainnya mengalami penurunan $\mathrm{pH}$. Pengamatan pada hari ke-4, menunjukkan sampel kontrol mengalami peningkatan yang sebelumnya mengalami penurunan $\mathrm{pH}$ pada hari ke-2. Hal ini diduga karena adanya pertumbuhan bakteri asam laktat yang pada kondisi anaerob dapat mengubah asam piruvat dari hasil glikolisis menjadi asam laktat (Dave dan Ghaly,
2011). Adanya asam laktat ini menyebabkan $\mathrm{pH}$ pada daging ayam giling menurun. Sedangkan terjadinya peningkatan $\mathrm{pH}$ disebabkan oleh adanya pemecahan protein menjadi senyawa volatil seperti ammonia. Senyawa ammonia ini dapat berinteraksi dengan air pada daging yang menyebabkan terbentuknya ammonium hidroksida yang bersifat basa sehingga $\mathrm{pH}$ meningkat (Amin, 2012). Pada hari ke-6 menunjukkan 
Tabel 4. Nilai TVB Daging Ayam Giling Dengan Penambahan Ekstrak Daun Salam dan Ekstrak Biji Pinang

\begin{tabular}{|c|c|c|c|c|c|}
\hline \multirow{2}{*}{ Konsentrasi Ekstrak } & \multicolumn{5}{|c|}{ Lama Penyimpanan (Hari) } \\
\hline & 0 & 1 & 2 & 4 & 6 \\
\hline A1 & $1,26^{\mathrm{A}}{ }_{\mathrm{a}}$ & $1,63_{b}^{\mathrm{B}}$ & $1,93_{\mathrm{c}}^{\mathrm{C}}$ & $2,48^{\mathrm{B}}$ & $3,53^{\mathrm{B}}$ \\
\hline B1 & $1,26^{\mathrm{A}}{ }_{\mathrm{a}}$ & $1,51_{b}^{\mathrm{AB}}$ & $1,66^{\mathrm{AB}}$ & $2,26^{\mathrm{A}}$ & $3,23^{\mathrm{AB}} \mathrm{d}$ \\
\hline $\mathrm{C} 1$ & $1,26^{\mathrm{A}}{ }_{\mathrm{a}}$ & $1,50^{\mathrm{AB}}{ }_{\mathrm{a}}$ & $1,66^{\mathrm{AB}}{ }_{\mathrm{a}}$ & $2,29^{\mathrm{AB}}$ & $3,31^{\mathrm{AB}}{ }_{\mathrm{c}}$ \\
\hline $\mathrm{A} 2$ & $1,26^{\mathrm{A}}{ }_{\mathrm{a}}$ & $1,43^{\mathrm{AB}}$ & $1,66^{\mathrm{AB}}$ & $2,30_{b}^{\mathrm{AB}}$ & $3,17_{\mathrm{c}}^{\mathrm{AB}}$ \\
\hline A3 & $1,26^{\mathrm{A}}{ }_{\mathrm{a}}$ & $1,48^{\mathrm{AB}} \mathrm{ab}$ & $1,70^{\mathrm{B}}$ & $2,27_{\mathrm{c}}^{\mathrm{A}}$ & $3,19^{\mathrm{AB}} \mathrm{d}$ \\
\hline B2 & $1,26^{\mathrm{A}}$ & $1,32^{\mathrm{A}} \mathrm{a}$ & $1,60^{\mathrm{AB}}$ & $2,23^{\mathrm{A}}$ & $3,03^{\mathrm{AB}}{ }_{\mathrm{d}}$ \\
\hline B3 & $1,26^{\mathrm{A}}{ }_{\mathrm{a}}$ & $1,34^{\mathrm{A}}{ }_{\mathrm{ab}}$ & $1,52^{\mathrm{AB}}$ & $2,21_{c}^{\mathrm{A}}$ & $3,05^{\mathrm{AB}}{ }_{\mathrm{d}}$ \\
\hline $\mathrm{C} 2$ & $1,26^{\mathrm{A}}{ }_{\mathrm{a}}$ & $1,29^{\mathrm{A}}{ }_{\mathrm{a}}$ & $1,44_{a}^{\mathrm{A}}$ & $2,18^{\mathrm{A}} \mathrm{b}$ & $2,92^{\mathrm{A}} \mathrm{c}$ \\
\hline $\mathrm{C} 3$ & $1,26^{\mathrm{A}}{ }_{\mathrm{a}}$ & $1,34^{\mathrm{A}}{ }_{\mathrm{ab}}$ & $1,53^{\mathrm{AB}}{ }_{\mathrm{b}}$ & $2,20^{\mathrm{A}}$ & $2,99^{\mathrm{AB}}{ }_{\mathrm{d}}$ \\
\hline
\end{tabular}

Keterangan : dalam $\mathrm{mg} / 10 \mathrm{~g}$ sampel

Huruf kecil yang sama pada kolom yang sama tiap parameter uji dan huruf besar yang sama pada baris yang sama menunjukkan tidak beda nyata pada taraf signifikansi $(\alpha=0,05)$

A1 : Penambahan ekstrak daun salam $0 \%$ dan ekstrak biji pinang $0 \%$ (kontrol)

A2 : Penambahan ekstrak daun salam $0 \%$ dan ekstrak biji pinang 2,5\%

A3 : Penambahan ekstrak daun salam $0 \%$ dan ekstrak biji pinang $5 \%$

B1 : Penambahan ekstrak daun salam $5 \%$ dan ekstrak biji pinang $0 \%$

B2 : Penambahan ekstrak daun salam $5 \%$ dan ekstrak biji pinang $2,5 \%$

B3 : Penambahan ekstrak daun salam $5 \%$ dan ekstrak biji pinang $5 \%$

C1 : Penambahan ekstrak daun salam $10 \%$ dan ekstrak biji pinang $0 \%$

C2 : Penambahan ekstrak daun salam $10 \%$ dan ekstrak biji pinang 2,5\%

C3 : Penambahan ekstrak daun salam $10 \%$ dan ekstrak biji pinang $5 \%$

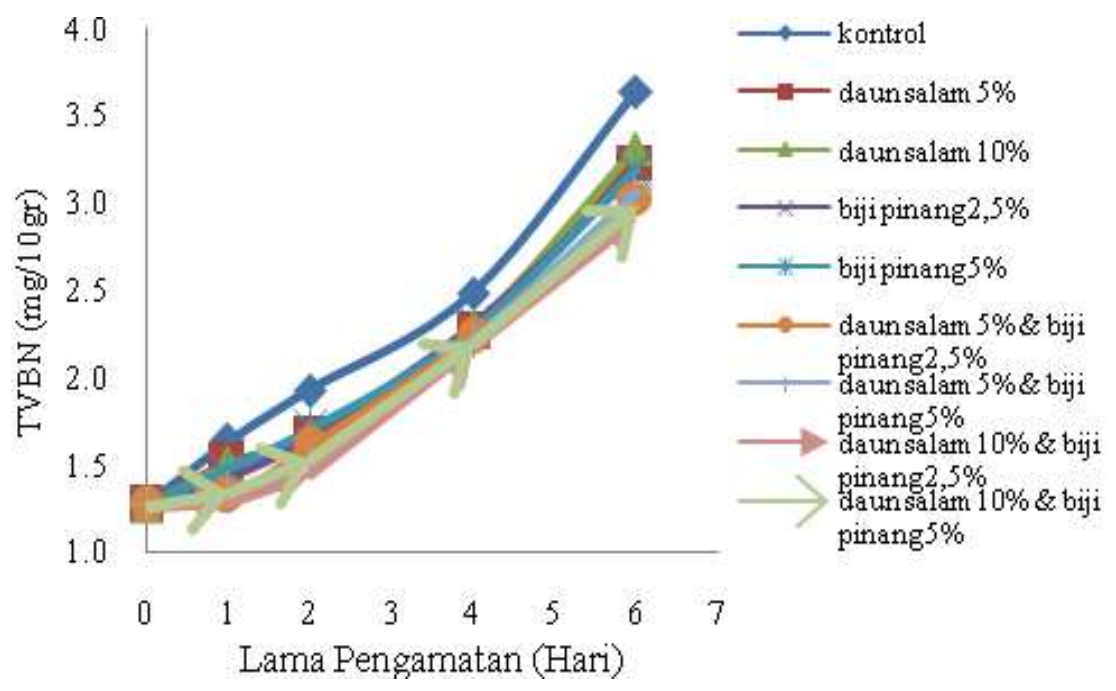

Gambar 4. Total Volatile Bases (TVB)

hampir seluruh sampel mengalami penurunan $\mathrm{pH}$, terutama pada sampel kontrol dan sampel dengan penambahan ekstrak daun salam $10 \%$, serta dengan penambahan ekstrak biji pinang 2,5\%, masing-masing menjadi 5,64; 5,69; dan 5,84 .

Dari grafik yang terlihat pada Gambar 3, menunjukkan bahwa $\mathrm{pH}$ awal daging yaitu 5,76. Pada umumnya $\mathrm{pH}$ daging adalah sekitar 5,4-5,8 setelah fase rigormortis (Soeparno, 2009). Hal ini sesuai dengan penelitian Urlings et al. (1993) bahwa $\mathrm{pH}$ awal daging ayam bagian dada yaitu 5,8. Selama waktu penyimpanan, diperoleh nilai $\mathrm{pH}$ yang fluktuatif. Namun, sebagian besar sampel memiliki tren penurunan $\mathrm{pH}$ pada hari ke- 
1, kemudian mengalami peningkatan sampai hari ke-4 dan mengalami penurunan kembali pada hari ke-6. Terjadinya penurunan $\mathrm{pH}$ pada hari ke-1 ini diduga karena adanya penambahan ekstrak daun salam dan biji pinang pada daging ayam giling yang menyebabkan pertumbuhan mikroba menjadi terhambat.

Pada hari ke-2 dan ke-4, sebagain besar sampel mengalami peningkatan nilai pH. Hal ini disebabkan adanya pembentukan komponen volatil basa nitrogen akibat dari perubahan biokimia pada suhu dingin dan meningkatnya pertumbuhan mikroba pada daging ayam giling sehingga menyebabkan hidrolisis protein menjadi senyawa volatil seperti ammonia yang dapat berinteraksi dengan air membentuk ammonium hidroksida yang bersifat basa (Amin, 2012). Akan tetapi, pada hari ke-4, terdapat beberapa sampel yang mengalami penurunan $\mathrm{pH}$. Hal ini disebabkan selama penyimpanan dingin pada keadaan vakum, bakteri asam laktat tumbuh lebih banyak dibandingkan dengan Pseudomonas sp. Adanya peningkatan pertumbuhan bakteri asam laktat menyebabkan terbentuknya asam laktat dari hasil pemecahan asam piruvat pada kondisi anaerob sehingga berpengaruh terhadap penurunan nilai $\mathrm{pH}$ (Dave dan Ghaly, 2011).

\section{Total Volatile Bases (TVB)}

Dari Tabel 4 menunjukkan bahwa secara keseluruhan nilai TVB pada masing-masing sampel meningkat seiring dengan lamanya waktu penyimpanan. Pada pengamatan hari ke-0 menunjukkan nilai TVB awal pada daging ayam giling sebesar 1,26 mg/10g sampel pada semua perlakuan. Pada pengamatan hari ke-1 menunjukkan peningkatan nilai TVB pada sampel yang diberi penambahan ekstrak. Pada sampel kontrol hari ke-1 menunjukkan nilai TVB sebesar 1,63 $\mathrm{mg} / 10 \mathrm{~g}$ sampel. Pada sampel dengan penambahan ekstrak daun salam 5\% dan $10 \%$ serta ekstrak biji pinang 5\% dan $10 \%$ menunjukkan nilai TVB meningkat secara signifikan, masing-masing menjadi 1,51; 1,$50 ; 1,43$, dan $1,48 \mathrm{mg} / 10 \mathrm{~g}$ sampel. Pada sampel dengan penambahan campuran ekstrak daun salam dan biji pinang tidak terlalu signifikan dengan nilai TVB sekitar $1,29-1,34 \mathrm{mg} / 10 \mathrm{~g}$ sampel. Pada pengamatan hari ke-2 menunjukkan sampel kontrol mengalami peningkatan nilai TVB paling signifikan menjadi 1,93 $\mathrm{mg} / 10 \mathrm{~g}$ sampel dibandingkan dengan sampel lainnya yang diberi perlakuan penambahan ekstrak daun salam dan biji pinang. Pada sampel dengan penambahan ekstrak salam $10 \%$ dan ekstrak biji pinang $2,5 \%$ tidak berbeda nyata mengalami peningkatan nilai TVB namun tidak signifikan sebesar $1,44 \mathrm{mg} / 10 \mathrm{~g}$ sampel. Pada hari ke-4, seluruh sampel telah mengalami kerusakan karena telah melewati batas maksimum nilai TVB yaitu 20mg/100g sampel (Amin, 2012). Hal ini menunjukkan pada pengamatan hari ke-4 sampel sudah tidak layak konsumsi karena mengandung TVB lebih dari $2 \mathrm{mg} / 10 \mathrm{~g}$ sampel. Peningkatan paling signifikan yaitu pada sampel kontrol menjadi 2,48 $\mathrm{mg} / 10 \mathrm{~g}$ sampel. Pada sampel lainnya tidak berbeda nyata, seperti pada campuran ekstrak daun salam dan ekstrak biji pinang hanya sekitar $2,18-2,27 \mathrm{mg} / 10 \mathrm{~g}$ sampel. Pada hari ke-6, nilai TVB semakin meningkat mencapai $3,6 \mathrm{mg} / 10 \mathrm{~g}$ sampel pada sampel kontrol. Pada sampel yang diberi perlakuan, nilai TVB tertinggi yaitu pada sampel dengan penambahan ekstrak daun salam $10 \%$ mencapai $3,31 \mathrm{mg} / 10 \mathrm{~g}$ sampel. Sedangkan, nilai TVB terendah yaitu pada sampel dengan penambahan ekstrak daun salam 10\% dan ekstrak biji pinang 2,5\% yaitu sebesar 2,92 mg/10g sampel. Hal ini dapat diduga bahwa campuran ekstrak daun salam $10 \%$ dan ekstrak biji pinang 2,5\% merupakan formula yang optimum karena memiliki efek sinergisme yang tinggi.

Dari Gambar 4, terlihat grafik hasil pengamatan uji TVB. Pada keseluruhan sampel menunjukkan adanya peningkatan nilai TVB seiring dengan lamanya waktu penyimpanan. Nilai TVB awal pada daging ayam giling sebesar $1,26 \mathrm{mg} / 10 \mathrm{~g}$ sampel. Hasil uji tersebut sesuai dengan penelitian yang dilakukan Dughaym et al. (2010) 
bahwa nilai TVB pada daging ayam giling sebesar $12,8 \mathrm{mg} / 100 \mathrm{~g}$ sampel.

Dari grafik tersebut terlihat bahwa pada pengamatan hari ke-1 nilai TVB belum meningkat secara signifikan dan belum mengindikasikan terjadinya kerusakan. Namun, setelah hari ke-2 pengamatan, mulai terjadi peningkatan nilai TVB secara signifikan sampai pada hari ke-6. Pada pengamatan hari ke-4, telah mengindikasikan adanya kerusakan yaitu nilai TVB melebihi $20 \mathrm{mg} / 100 \mathrm{~g}$ sampel (Desouky, 2006). Hal ini disebabkan pecahnya protein dari hasil aktivitas mikroba di bawah suhu rendah dan enzim autolitik dan proteolitik. Selain itu, peningkatan nilai TVB juga dapat dipengaruhi oleh produksi basa volatil seperti $\mathrm{NH}_{3}$, TMA, DMA, dan hipoxantin dan juga dapat dipengaruhi oleh senyawa non-volatil seperti histamin. Asam lemak bebas dari hasil deteriorasi lipid juga dapat mempengaruhi peningkatan nilai TVB (Amin, 2012).

\section{KESIMPULAN}

1. Penambahan ekstrak daun salam (Syzygium polyanthum) dan ekstrak biji pinang (Areca catechu L.) dapat menghambat kerusakan mikrobiologis sampai pada hari ke-6 yaitu sebesar 6,89 $\log \mathrm{cfu} / \mathrm{g}$ sampel pada campuran ekstrak daun salam 10\% dan ekstrak biji pinang 2,5\% dan dapat menghambat kerusakan kimiawi sampai pada hari ke-2 yaitu sebesar $1,44 \mathrm{mg} / 10 \mathrm{~g}$ sampel pada campuran ekstrak daun salam 10\% dan ekstrak biji pinang 2,5\%.

2. Penambahan ekstrak daun salam (Syzygium polyanthum) dan ekstrak biji pinang (Areca catechu L.) dapat menghambat kerusakan mikrobiologis dan kimia daging ayam giling selama 2 hari penyimpanan suhu $2^{\circ} \mathrm{C}$.

3. Penambahan ekstrak daun salam (Syzygium polyanthum) dan ekstrak biji pinang (Areca catechu L.) yang paling efektif yaitu pada campuran ekstrak daun salam $10 \%$ dan ekstrak biji pinang $2,5 \%$.

\section{DAFTAR PUSTAKA}

Amin, R. 2012. Effect of Bio Preservation as a Modern Technology on Quality Aspects and Microbial Safety of Minced Beef. Global Journal of Biotechnology and Biochemistry 7 (2) : $38-49$.

Apriyantono, A.D., Fardiaz, N.L., Puspitasari, S., dan Budiyanto S. 1988. Analisa Pangan. IPB Press. Bogor.

Dave, D. dan Ghaly. 2011. Meat Spoilage Mechanisms and Preservation Techniques : A Critical Review. American Journal of Agricultural and Biological Sciences Vol. 6 No. 4 : 486 -510 .

Deepa, G., Ayesha, S., Nishtha, K., dan Thankamani, M. 2013. Comparative Evaluation of Various Total Antioxidant Capacity Assays Applied to Phytochemical Compounds of Indian Culinary Spices. International Food Research Journal Vol. 20 No. 2 : 1711 - 1716.

Desouky, E., Bahlol, H.E.M., dan Sharoba, A.M.A. 2006. Effect of Some Essential Oils and Preservatives On The Growth of E. coli O157 : H7 and Quality of Refrigerated Mince Meat. Annals of Agriculture Science Vol. 44 (4) : $1675-1695$.

Doyle, E. 2007. Microbial Food SpoilageLosses and Control Strategies. FRI Briefings. Food Research Institute.

Dughaym, A., Altabari, G.F., dan Hamdy, M. 2003. Safety and Quality of Chicken Meat Products. Universitas King Faisal, Arab Saudi.

Fardiaz, S. 1987. Mikrobiologi Pangan. Lembaga Sumberdaya Informasi IPB. Bogor.

Food Safety and Standards Authority of India. 2012. Meat And Fish Products. India.

Gani, M., Cuaca, Y., Ayucitra, A., dan Indraswati, N. 2013. Ekstraksi 
Senyawa Fenolik Antioksidan Dari Daun dan Tangkai Gambir. Jurnal Teknik Kimia Indonesia Vol. 11, No. $5: 250-256$.

Hannan, A., Karan, S., dan Chatterjee, T.K. 2012. A Comparitive Study of InVitro Antioxidant Activity of Different Extracts of Areca Seed Collected From Areca catechu Plant Grown In Assam. International Journal of Pharmacy and Pharmaceutical Sciences Vol. 4.

Jaiswal, P., Kumar, P., Singh, V.K., dan Singh, D.K. 2011. Areca catechu L. : A Valuable Herbal Medicine Against Different Health Problems. Research Journal of Medicine Plant Vol. 5 No. $2: 145-152$.

Lin, M., Al-Holy, M., Mousavy-Hesary, M., Al-Qadiri, H., Cavinato, A.G., dan Rasco, B.A. 2004. Rapid and Quantitative Detection of The Microbial Spoilage In Chicken Meat By Diffuse Reflectance Spectroscopy $(600-1100 \mathrm{~nm})$. Letters in Applied Microbiology, 39 : 148 - 155.

Makkar, H.P.S., Blummel, M., Borowy, N.K., dan Bekker, K. 1993. Gravimetric Determination of Tannins and Their Correlations With Chemical and Protein Precipitation Methods. Journal Sciences Food Agricultural, 61: $161-165$.

Mawaddah, R. 2008. Kajian Hasil Riset Potensi Antimikroba Alami dan Aplikasinya Dalam Bahan Pangan di Pusat Informasi Teknologi Pertanian FATETA IPB. Skripsi.

Muwarni, R. 2012. Preservatives For Meat Products. Food Review Vol. VII No. 8, Agustus 2012.

Olaitan, A., Chukwudi, U., dan Margaret, Y. 2010. Antimicrobial Potentials of Some Spices On Beef Sold in Gwagwalada Market, FCT, Abuja. Academia Arena 2010 : 2 (7).
Puspawati, N. 2008. Uji Aktivitas Antibakteri Ekstrak Etanolik Biji Pinang (Areca catechu L.) Terhadap Staphylococcus aureus ATCC 25923 dan Pseudomonas aeruginosa ATCC 2785. Universitas Setia Budi, Surakarta.

Puspita, F.S. dan Muktiana, S.S. 2011. Ekstraksi Zat Aktif Antimikroba Dari Tanaman Yodium (Jatropha multifida Linn) Sebagai Bahan Baku Alternatif Antibiotik Alami. Jurusan Teknik Kimia, Fakultas Teknik, Undip.

Soeparno. 2009. Ilmu dan Teknologi Daging. UGM Press. Yogyakarta.

Urlings, H.A., Fransen, N.G., Bijker, P.G., Logtestijn, J.G. 1993. Proteolysis and Amino Acid Breakdown of Heated and Irradiated Poultry Byproducts and Muscle Tissue. Journal of Animal Science $71: 2432-2438$.

Vardapetyan, H., Tiratsuyan, S., Hovhannisyan, A., Rukhyan, M., dan Hovhannisyan, 2013. Phytochemical Composition and Biological Activity of Laurus nobilis L. Leaves Collected From Two Regions of South Caucasus. Journal of Experimental Biology and Agricultural Sciences Vol. 1 No. 2.

Wetwitayaklung, P., Phaechamud, T., Limmatvapirat, C., dan Keokitichai, S. 2006. The Study of Antioxidant Capacity In Various Parts of Areca catechu L. Naresuan University Journal Vol. 14 No. 1 : 1 - 14.

Zhang, W.M., Wei, J., Chen, W., dan Zhang, H.D. 2011. The Chemical Composition and Phenolic Antioxidants of Areca (Areca catechu L.) Seeds. International Conference on Agricultural and Biosystems Engineering Advances in Biomedical Engineering Vol. 1-2. 